\title{
BARRIERS TO INNOVATION AND SUSTAINABILITY AT UNIVERSITIES AROUND THE WORLD
}

Lucas Veiga Ávila, Walter Leal Filho*, Luciana Brandli, Collin MacGregor, Petra MolthanHill, Pinar Gökçin Özuyar, Rodrigo Martins Moreira

\section{V. Ávila}

State University of Rio Grande of South and Federal University of Santa Maria, PhD program in Administration. Avenue Roraima, 1000, Camobi Neighborhood - Room 4303 ZIP Code 97105900 - Santa Maria, RS, Brazil, E-mail: admlucasveiga@gmail.com

\section{${ }^{*}$ W. Leal Filho* (Corresponding author)}

World Sustainable Development Research and Transfer Centre, Faculty of Life Sciences, Hamburg University of Applied Sciences, Lohbrügger Kirchstraße 65, 21033 Hamburg, Germany, E-mail: walter.leal@ haw-hamburg.de

\section{L. Brandli}

Graduate Program in Civil and Environmental Engineering, University of Passo Fundo, CAMPUS I-Km 171-BR 285, Bairro São José, Caixa Postal 611-CEP 99001-970, Passo Fundo/RS, Brazil, E-mail: brandli@upf.br

\section{MacGregor}

Senior Lecturer, Sustainability. College of Science \& Engineering in James Cook University. PO Box 6811. Cairns, Queensland 4870, E-mail: colin.macgregor@jcu.edu.au

\section{P. Molthan-Hill}

Principal Fellow of the Higher Education Academy (PFHEA) Team Leader NTU Green Academy Project 'Food for thought' NBS Sustainability Coordinator. Principal Lecturer in Business Sustainability Nottingham Business School, England, E-mail: petra.molthan-hill@ntu.ac.uk

\section{P. G. Ozuyar}

Faculty of Business. Sustainability Initiatives Advisory and Coordination (SIAC)

BlackSea Industrial Symbiosis Platform (BSISP). Cekmekoy Campus, Istanbul, Turkey, Email: pinar.ozuyar@ ozyegin.edu.tr

\section{R. M. Moreira}

$\mathrm{PhD}$ Candidate at Sciences of Environmental Engineering Program School of Engineering of São Carlos - University of São Paulo School of Natural Resources and Environment - University of Michigan, United States E-mail: rodrigo.mart@usp.br 


\begin{abstract}
This paper explores the link between innovation and sustainability in the context of higher education, with the purpose of investigating the fundamental barriers for innovation and sustainable development in universities around the world. The method used involves both a quantitative and a qualitative approach, gathering the views of 301 experts from 172 universities across all continents. The results show that there are similar barriers across different geographical regions that require greater support from university administrations and management. In particular, the willingness of leaders, policy makers and decision-makers to envisage a sustainable future inside universities is often missing. Yet, without the support of senior management within a university, bottom-up sustainable initiatives seem destined to fail in the longer term due to a lack of investment and administrative support. This study also identifies that in order to yield the anticipated benefits, barriers need to be tackled in an integrated way, and that closer cooperation between sustainability researchers, university administrations and students is needed.
\end{abstract}

Key words: sustainable development; innovation; sustainability; higher education; barriers; research

\title{
1. Introduction
}

Much has been written about teaching and research that is focused on sustainable development (Posch and Steiner, 2006) and the development of eco-innovation (Del Rio, Carrillo-Hermossilla and Könnöla 2010; Hellström 2007). Comparatively little literature, however, can be found that focuses on the nexus between innovation and sustainable development. Despite this, there is a very close relationship between innovation and sustainability (Vollenbroek, 2002).

Indeed, these two processes are highly related since, when they converge, they often result in long term impacts and benefits. The relationship between innovation and sustainability can be better understood if one considers their respective structures and areas of application. A closer look at these two processes allows for the identification of the fact that there are two main types of innovation when it comes to sustainable development:

a) Structural innovation, which involves changes in structures, hierarchies and governance in an organization; for instance, the appointment of a sustainability coordinator at a university to oversee its efforts in this field;

b) Operational innovation, which refers to the introduction of tools which may enhance and maximize the operations of the institution; for example, the use of energy-saving bulbs.

Albeit rather simple and straightforward to understand in principle, these two main types of sustainable development focused innovation are characterized by the need to carefully reflect on their degree of applicability before they may be implemented. This fact lends them some degree of complexity. It is a fact that changes in the organization of a university are not easy, and that the appointment of a sustainability coordinator, for example, may not a matter 
enough for each university to do for financial reasons. Therefore, one has to assess the conditions at each institution before an innovation or initiative in support of sustainable development can be fully realized at the institutional level.

Therefore, one question that arises is, how can innovation and sustainability be integrated in order to maximize their advantages for universities? The answer to this question is not so simple, since a variety of factors - including support from the top level - may interfere with the likelihood that a specific type of innovation is implemented at a university. A second element which should be outlined is the fact that there are four main principles which guide innovation in the field of sustainable development, knowledge of which is necessary to allow their integration to succeed. Due to their importance, these four main principles will be described below:

Principle 1- Ingenuity: innovation is often the implementation of a simple idea put towards a greater use. The use of surface or sub-surface rainwater storage tools, as implemented by the Hamburg University of Applied Sciences (Germany) as part of the project AFRHINET (http://afrhinet.eu/) in Africa - to supply plantations with water in the dry seasons , or to help to water gardens - is a very simple, yet quite efficient procedure to support agriculture and crop production, especially in developing countries.

Principle 2- Simple implementation: the best types of innovation in the field of sustainable development are those that are simple and easy to implement. At Manchester Metropolitan University (UK), for example, efforts to manage waste and recycle paper have yielded greater benefits when the containers to gather waste or paper were placed not in each classroom - as is often the case - but in the corridors instead. This means that greater amounts of waste (e.g. paper, cans, and general litter) can be collected with less effort, since cleaning personnel do not need to enter each classroom to collect it.

Principle 3- Environmental efficiency: some types of innovation can lead to real impacts in areas such as energy consumption and reductions in $\mathrm{CO} 2$ emissions. One example is seen at many universities in North America, where lavatory lights have motion sensors, which means that their lights are by default off unless someone enters the room when the lighting is activated. The lights go off again, once that person leaves the room. Also, across the world, water efficient taps are being used: with one push, a certain amount of water flows for a few seconds and then automatically stops. This leads to greater environmental efficiency and results in decreased pressure on environmental resources.

Principle 4- Economic viability: innovation in the field of sustainable development can also help to reduce costs and minimize the loss of financial resources. For instance, in universities across the world, millions of kilowatts of energy are wasted powering printers and computers etc. when they're not in use, resulting in substantial amounts of needless expenditure. While computers and notebooks are typically used all day, most printers are used for only a few minutes in each working day, despite the fact that they are switched on continuously. A simple innovation such as only turning printers on when they are needed can substantially reduce both the energy consumption and the energy bill of a university.

These principles are derived from both the experiences of the authors on sustainability, such as Leal Filho (2006) on a compendium on innovation, education and communication for sustainable development, and also from a volume which explores innovative approaches to 
education for sustainable development (Leal Filho and Salomone 2006). Further, some important published works on innovation and competence development (Barth al 2007) and on post-graduate training (Gombert-Courvoisier et al 2014) have analysed the role and relevance of innovation with regards to sustainable development.

Unlike other areas, innovation in sustainable development is not characterized by a great degree of uncertainty: if properly implemented, it is proven to work. Sustainable development innovation can be simple to achieve provided it is based on a strong idea, and seldom entails any risks. Further, innovation in sustainable development may be advantageous to universities in a variety of ways, as outlined in Figure 1.
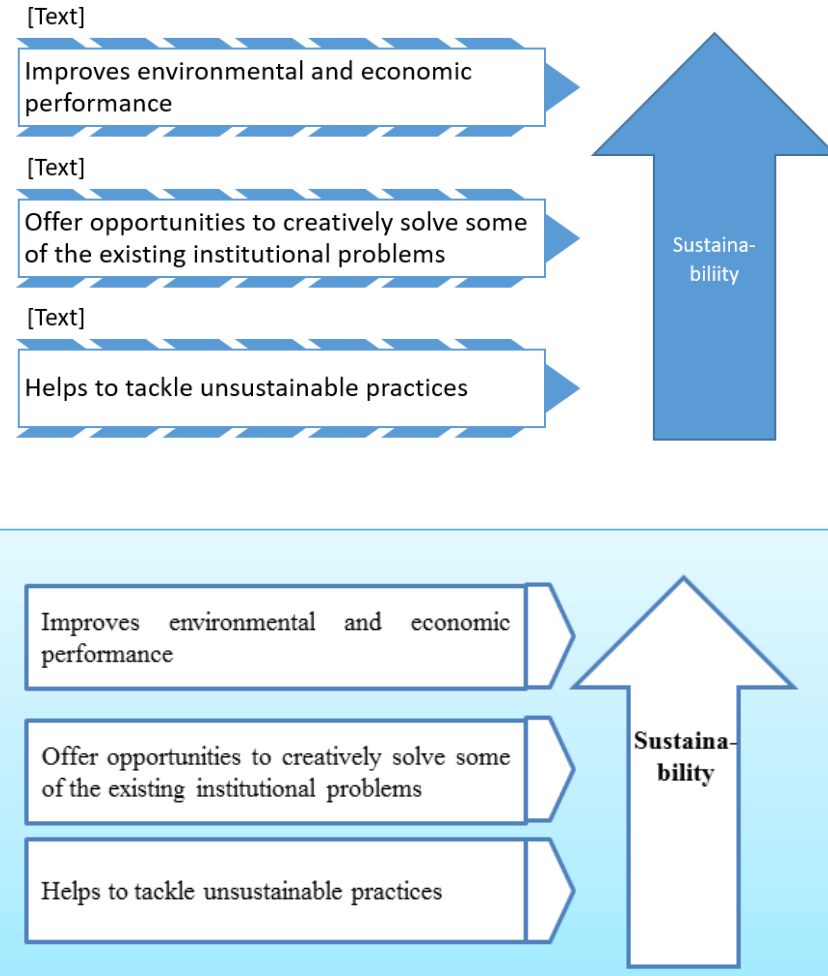

\section{Figure 1- Advantages of innovation in sustainable development to universities}

Nevertheless, despite the fact that universities are faced with increasing pressure to make use of their resources and consider sustainable development as part of their operations, many are still reluctant to revise their business models and incorporate the necessary changes. 
Part of the problem is that the investments required are often seen as a barrier, whereas the benefits with respect to both environmental and economic performance are often overlooked.

This paper explores the links between innovation and sustainability within the context of higher education. This is done with the purpose of investigating the fundamental barriers for innovation and sustainable development in universities around the world.

\section{The problems seen in innovation in sustainable development at universities}

Pursuing sustainability at universities is one of the main strategies to strengthen society, especially where aspects of social and economic equity and a healthy environment are taken into account, by means of teaching, research and outreach practices (Stir, 2006; Lozano et al., 2013). University campuses can be understood as small towns, and it is possible to transform such spaces as habitats for the development and implementation of new social and technological innovations and as pilots for management strategies regarding sustainability (Evans et al., 2015; Alshuwaikhat and Abubakar, 2008). The implementation of sustainability at universities can expand their innovation potential, both within and outside the campus walls. This can facilitate a continuous learning process between academia, local municipalities and the private sector (Trencher, 2014).

Velazquez et al. (2005) identified four main strategies for universities to advance innovation in sustainability: education, research, outreach/community and sustainability on campus. This is similar to the 4C-model proposed by Jones, Selby, and Sterling (2010) which acknowledges the role of sustainable development and innovation in Campus, Curriculum, Community and Culture. It is natural that each of these four areas has obstacles and challenges, which will be discussed later in this paper. But one of the major issues identified in previous research is the lack of a holistic vision and of integrated approaches to innovation. This is linked to the often lacking commitment of senior managers to embrace change and strive for sustainable solutions, within and beyond the university.

Most sustainable innovations have focused on the campus of a university. Here, operational innovations such as renewable energy installations, initiatives with solar arrays, wind turbines, geothermal projects, biomass production facilities, conservation retrofits, and energy efficient designs have been introduced (Thomashow, 2014). As Leal Filho et al (2015) have showed, campus greening has a clear connection with innovative projects, transfer of models for the surrounding community and the possibility to implement innovative green technologies. The popularity and influence of university rankings has spawned large numbers of accreditation schemes (Lauder et al, 2015). For example, Ecocampus (2017) and rankings such as the People \& Planet League in the UK were centered initially on the environmental management of a university. More recently, the attention has shifted and attempts have been made to include the core activities of a university, namely research, education and environment indicators rankings (Lukman, Krajnc and Glavic, 2010). In terms of the curriculum, many universities are still lagging behind and offer courses and programmes which either partly or completely fail to incorporate aspects of sustainable development (Capdevila, Bruno and Jofre, 2002; Müller-Christ, 2014). As far as research is concerned, even though there is a plethora of scientific work and various studies published, they most often use well known methods and techniques (e.g. surveys) but do not always exercise care to ensure the validity or 
reliability of their data when it comes to innovation. As a result, many studies tend to repeat trends as opposed to offering a basis for ground-breaking innovation. The most common innovation in teaching and research is the availability of separate offerings, so for example a Master in CSR (Corporate Social Responsibility) or a research centre focusing on sustainable development or climate change. This has not been matched by structural innovations to embed sustainability or sustainable development across the curricula and across research centers.

With respect to community and student engagement, only a few universities have a vision of how all of these areas may support one another. There are some recent accreditation schemes which appear promising, such as the UK LiFE (Learning in Future Environments) Index, which encourages a holistic view of the university by considering four themes: leadership and governance, partnerships and engagement, facilities and operations, and teaching and research. However, many universities still miss opportunities to strategically link between these areas.

The willingness of leaders, policy makers and decision-makers to envisage a sustainable future inside universities is often lacking (Richardson and Lynes, 2007). Without the support of senior management within a university, bottom-up sustainable initiatives seem destined to fail in the longer term due to a lack of investment and administrative support. To develop this kind of initiative requires considerable amounts of time and financial resources, which are difficult to obtain without the support of the upper administration. As a result, staff and student entrepreneurs in sustainability often fail to progress with such initiatives.

Furthermore, appropriate instruments are often not in place because senior management tends not to define specific goals in this area, nor do they agree on a holistic vision. However, setting goals is important to define the intentions of the university with respect to sustainability as a whole, and in particular when it comes to innovation for sustainable development. Wright (2002) suggests that the University of Waterloo, the University of South Carolina, the University of Buffalo, the University of Toronto, and George Washington University, are examples of universities that have become leading universities in sustainability by elaborating and accomplishing their sustainable vision, objectives and goals.

Regardless of all of the outcomes achieved in implementing sustainability practices at universities, the examples provided by the many "role models" show that they also have to deal with obstacles (Hansen and Lehmann, 2006). Some of the specific challenges seen in order to pursue and improve campus sustainability are (Bero et al., 2012; Alnsour and Meaton, 2015):

-A diverse community of students, faculty and staff, varying in their priorities and level of engagement;

-A great diversity of buildings and activities that include offices, laboratories, dining halls, dormitories and maintenance;

- A broad distribution of age and cultural perspectives;

-Limited financial and human resources for developing, implementing and maintaining sustainable initiatives.
Commented [LA4]: Adjusted 
The Cambridge Programme for Sustainability Leadership (Courtice and Van der Kamp, 2013) found that within a complex organization, sustainable leadership depends among other things - on the capability to employ systems thinking. Leaders with a sustainable vision need to allow innovation to emerge bottom-up, through all the business practices within the organization, as well as implementing it top-down, through strong leadership directives.

A university that is seeking a more sustainable path, either on an initial phase or a plan that is already more advanced, will face a series of internal and external barriers (Brandli et al., 2015). Dealing with these barriers in a systematic way is important to make the initiatives work in an effective and continuous flow, and not to lose the interest of the people engaged. Therefore, universities are seeking to enhance their levels of innovation in sustainability issues through tools such as certification, environmental management systems and the development of effective policies. These instruments should help to overcome challenges, partly by creating a sense of identity for the university community (Clarke and Kouri, 2009).

Morland-Painter et al. (2015:18) argued that integrating sustainability into the curriculum must be closely aligned with systemic institutional integration, which they define as: 'building a systemic capability towards sustainability, distributed and nurtured throughout the organization, which creates the impetus towards change in students, faculty, administrators, the institution as a whole, as well as organizations that hire its alumni'. Their findings indicate that there are insufficient incentives for faculties to integrate sustainability into their research and teaching activities. Often, sustainability entrepreneurs have to do these activities in addition to their normal duties. Human resources policies regarding hiring, annual performance reviews and promotion often do not reward sustainable innovation either.

These missing holistic visions and incentives are matched by transdisciplinary barriers and a tendency for academics and departments to focus on one specific discipline in teaching, and on an even more reduced topic in their research activities. Lozano et al. (2013: 10) argue that, 'In spite of a number of sustainable development (SD) initiatives and an increasing number of universities becoming engaged with SD, most higher education institutions (HEIs) continue to be traditional, and rely upon Newtonian and Cartesian reductionist and mechanistic paradigms'.

Several academics have argued that highly specialized yet specific 'areas of knowledge' are encouraged within universities and few incentives are given to encourage trans-disciplinary collaboration. Universities therefore 'produce' graduates who have a narrow understanding of their own discipline with a focus on 'individual learning and competition professionals who are ill prepared for cooperative efforts' (Cortese, 2003; Winter and Cotton 2012; Djordjevic and Cotton 2011). Any effort to integrate sustainability in a university context has to address these systemic issues in order to overcome communication barriers and to integrate highly specialized knowledge. Aalborg University, for example, has taken this approach: students from different disciplines have to study around ten projects during their degree to find solutions for real-life sustainability problems (Simon and Lundebye, 2013).

In connection with this issue, the role played by a lack of internal political instruments, such as policies, plans and programmes can also be seen. These instruments are important for the strengthening of sustainable initiatives because they provide a legal background (Pereira, 2014). Research by Ryan et al. (2010) indicates the importance of policies in supporting the 
smooth delivery of SD in the HE curriculum, including mechanisms such as open and clear communication. Furthermore, changes in quality assessment and quality enhancement processes are needed to support the delivery of 'effective learning and innovation for sustainability' (Ryan and Tilbury, 2013:273).

Five other thematic obstacles identified from the literature review will now be considered.

\section{i.Lack of specific working groups, committees and sustainability offices}

The existence of formal groups of committees or, ideally, dedicated sustainability offices, is important in order to offer guidance. They need to be trans and multidisciplinary and hierarchically multi-leveled, which may prevent conflicts of interests arising from within these groups.

By creating settings such as "offices of sustainability" a university is able to hire someone to deal (full-time or on a part-time basis) specifically with sustainability, as well as creating a hierarchical position that fills the gap of leadership amongst the minor stakeholders with decision-making power. The lack of a person to deal specifically with these issues inside a university translates into the weakening of the sense of identity of the university community. Having someone or some specific place to address doubts or observations about sustainability issues is essential (Gudz, 2004)

Even for those cases where there is a dedicated person, the roles and responsibilities may be confusing; an administrative or technical person may face resistance or they may lack the necessary support from the local academia. For example, if an academic person is delegated to the role, the issues and concerns regarding operations and infrastructure may go unnoticed.

The University of Waterloo, by means of its WATgreen committee, developed a study that allowed the university to perceive a series of weaknesses and barriers for its successful green building projects within the campus, as well as presenting decision-makers with recommendations about the matter (Richardson and Lynes, 2007).

\section{ii.Cultural and behavioral change}

In a case study developed at the University of Technology of Mara (UiTM) - Malaysia, the authors concluded that pursuing sustainability at universities demands fundamental changes in the mindset and lifestyle of its community, where trans and multidisciplinary initiatives are required. Since sustainability is a broad issue that requires cooperation at multiple hierarchical levels, isolated efforts may therefore be limited in terms of their impact (Saleh et al., 2011).

This is corroborated by Levy and Marans (2012) through a case study at the University of Michigan, who suggest that cultural changes are the best way to pursue sustainability. In this paper, the researchers analysed the identity of its community regarding sustainability issues and presented them to the decision-makers. The authors also presented key actions that could lead to a more sustainable campus. These included: education/training through coursework; eco-certification and community training; engagement through cultural liaison, competitions and unit initiatives; and, assessment/monitoring through cultural indicators and barrier surveys. 
Changes made by decision-makers directly affect the continuity of sustainability initiatives. Due to changes in deans every four years, the environmental and sustainable profile of a given university can also change, as a result of divergent interests or priorities. Larrán Jorge et al. (2014) discussed an approach to implement sustainability at Spanish universities in their paper, and they identified how the senior management's will, opinion and perception of the university's initiatives on sustainability were key for success.

\section{iii Lack of financial resources}

Elliot and Wright (2013) interviewed 27 Canadian university student unions' presidents. They found that the greatest barrier to university sustainability was a lack of financial resources. This was almost always the first (and main) barrier mentioned by the respondents.

The financial resources of universities are usually related to the number of students enrolled, the number of top research projects being developed, and by political influence. Unfortunately, the environmental and sustainability field of research suffers by not being an area of priority. This makes the whole chain fragile. What results is the deployment of sustainable initiatives working on low incomes of funding and staffed and delivered most of the time through the work of volunteers (Velazquez et al., 2005).

\section{iv.Lack of engagement between municipalities, companies and universities}

In general, the engagement of municipalities and the private sector within universities consists of activities regarding capacity building, community outreach and problem based research (Perkman et al., 2013; Shiel et al.,2016). Community outreach programs are kept on a social level mainly through the initiation of academic staff or student bodies. Problem based research, on the other hand, targets the cooperation of academia towards the pursuit of a solution to an existing specific problem within the local municipality or the private sector. In a study carried out by Perkman et al. (2013), it is proposed that when it comes to university and industry cooperation, academic engagement is positively correlated with individual characteristics that define senior, scientifically productive individuals. This indicates that it is in line with the development of academic research activities, resulting in engagement being less organizationally embedded but rather autonomously driven by individuals.

Alnsour and Meaton (2015) discussed the results of a study regarding the use of research data by Jordanian planning authorities in their decision making processes, along with the main factors that affect the use of research. Their findings revealed that the use of research was quite low owing to various factors including: legal, administrative and technological issues, in addition to financial, social and people related challenges.

Universities have the potential to play a leading role in enabling communities to develop more sustainable ways of living. However, sustainable communities may only emerge when there is the necessary facilitation, community learning and continual efforts to build their capacities. Although capacity building and the promotion of sustainable development locally, are on the agenda of most universities that take local and regional engagement seriously, very little is published that illustrates or describes the various forms of activities that take place in support of this. Further, there is a paucity of studies that have evaluated the work performed by universities in building capacity for sustainable development at the local level (Shiel et al.,2016). 


\section{v. Lack of reporting and accountability mechanisms}

The United Nations has initiated the United Nation's Decade of Education for Sustainable Development (2005-2014) and various other education for SD declarations. This includes the Talloires Declaration, 1990 (ULSF, 2007), which was the first official statement made by university presidents, chancellors and rectors related to sustainability. However, these declarations largely lack discussion on a requirement for reporting or accountability mechanisms. Lozano et al. (2013) propose that, although these initiatives are intended to serve as supporting, guiding, and challenging documents, they alone cannot ensure that the signatory institutions implement SD within their organizations. There might also be institutions that have not yet signed a declaration or belong to any charter, but which are nonetheless actively engaged in SD on their campuses.

Other significant reporting tools are AASHE's (The Association for the Advancement of Sustainability in Higher Education) STARS and ISCN's (International Sustainable Campus Network) Gulf Charter Report. STARS (Sustainability Tracking, Assessment \& Rating System) is a transparent, self-reporting framework for colleges and universities to measure their sustainability performance designed for US universities, while the ISCN targets a global member database of around 90 universities. The LiFE Index is another similar transparent, self-reporting framework that is being increasingly utilized in Australasian universities and colleges of advanced education (Macgregor, 2015).

An analysis made by Yarime and Tanaka (2012) on16 accounting tools between 1993 and 2010, indicated that existing sustainability assessment tools are not sufficiently addressing the importance of education, research and outreach activities in universities. In the aforementioned study, a close look at the indicators and questions included in many assessment tools revealed they tend to consider the environmental impacts of university operations and issues related to governance.

Furthermore, a lack of detailed reporting and accountability mechanisms makes it difficult for universities to track their in-house achievements or inadequacies in order to support policies and learn from others' experiences.

\section{Methodology}

Definitions of innovation and sustainability are numerous and clearly these terms refer to different phenomena; however, in terms of adoption, there are common themes and barriers within both (Bessant, Tidd, 2009). The research reported in this paper explores the barriers of adopting innovation and sustainability initiatives within universities.

A mixed methods approach involving quantitative and qualitative methods was adopted for this study (Phase 1 and Phase 2). It consisted of an online survey performed via the software "Survey Monkey" where both university administrators and researchers were asked to fill in a questionnaire with a set of questions related to the barriers they see and perceive at their institutions when pursuing sustainability. A total of 301 respondents from 172 universities around the world participated in the two phases of the research. 
This design made it possible to elaborate a descriptive statement about a grouping and perform a description of trends and attributes, in addition to serving as a search engine about the context examined which would meet the definitions of Babbie (2009). The data was collected at various points in time throughout 2016 and was synthesized statistically (Hair et al., 2010).

\section{Phase 1 - Qualitative Approach}

i. Aim: to identify the main barriers to innovation and sustainable development in universities worldwide and to have arguments to develop the questionnaire for use in Phase 2.

ii. Sample: In total, there were 51 respondents from Australia, Colombia, Ghana, South Africa, Austria, Cote d'Ivoire, Guatemala, Spain, Ecuador, Japan, Sweden, Brazil, England, Nigeria, Uganda, Chile, Finland, Philippines, United States, China, Germany, Portugal and Philippines. Those selected were: rectors of universities participating the Green Sustainability Metrics (2016); office managers of universities participating in the Green Sustainability Metrics; 20 researchers with significant numbers of publications on the subject in the database Web of Science; professors/lecturers and researchers with peer-reviewed impact publications on the subject of sustainability at universities

iii. Data collection: Data was collected during July and August 2016 using the Survey Monkey software, with the following questions: a) what is your position today in the institution? b) What are the main barriers encountered in the practices of sustainability related innovation in universities? c) Which processes/initiatives are most appropriate to increase the sustainable innovation capacity in universities? d) How can sustainability contribute to the creative process? e) How can sustainability/leverage the innovation process? f) Which partners are essential to engage in the process of innovation in universities? g) How can sustainability be incorporated into the innovation process in universities? h) What are the major gains that the university may obtain in adopting innovation and sustainability in its philosophy and in their practices? To carry out this study, the results were selected regarding answers to the following question: what are the main barriers encountered in innovation related to sustainability practices in universities?

iv. Analysis procedure: The qualitative approach adopted here followed the experiences documented by Bardin (2011). The technique involves reading and interpreting the material in a progressive and systematic way so that an inductive, constructive output emerges (Moraes, 1999). This resulted in a categorization of data. Following Vergara (2005), the categories were rearranged primarily based on the frequencies of common themes. Moraes (1999) suggests the following steps be applied: preparation of information (and encoding); notarization or transformation of the content into units of analysis; categorization or classification of units in categories; description; and interpretation and statistical treatment. The operationalization of the review process took place with the support of Nvivo software, which has been developed specifically to support qualitative studies (Mozzato and Grzybovski, 2001). 


\section{Phase 2 - Quantitative Approach}

i. Aim: to evaluate the degree in which barriers influence the process of innovation and sustainable development at universities.

ii. Sample: In total, there were 250 respondents from the following countries: Australia, Austria, Belarus, Belgium, Brazil, China, Cote d'Ivoire, Croatia, Czech Republic, Denmark, Ecuador, Finland, France, Germany, Ghana, Guatemala, Hong Kong PRC, India, Iran, Ireland, Italy, Japan, Latvia, Lithuania, Malta, Mauritius, México, Mongolia, Nigeria, Philippines, Poland, Portugal, Qatar, Scotland, Serbia, Singapore, South Africa, Spain, Syrian Arab Republic, Tanzania, Thailand, The Netherlands, The Republic of Belarus, Turkey, Uganda, United Kingdom and United States. With regards to a criteria of selection, the potential respondents were partly identified at the World Symposium on Sustainable Development at Universities, which was held $14^{\text {th }}$ to $16^{\text {th }}$ September 2016 at the Massachusetts Institute Technology in the United States of America.

When it came to data collection, notifications were sent to potential respondents via email, inviting them to answer the questionnaires (available online from 10th the September to October 15th, 2016) using Google Docs ${ }^{\circledR}$.. The quantitative questionnaire was built according the content analysis, grouping similar words and similar attribute values obtained from the qualitative approach. This procedure indicated 25 categories of barriers, that generated 25 questions constructed around a 5-point likert scale (Likert, 1932) to measure the degree to which respondents agreed or disagreed with statements related to the barriers: $5=$ totally agree; $4=$ Agree; $3=$ Neutral; 2 = Disagree; 1 = Totally disagree. Malhorta (2006) confirms that the Likert scale enables respondents to indicate their degree of agreement (or disagreement) to statements about stimulus objects. In this case, the stimuli were barriers to sustainable development in universities.

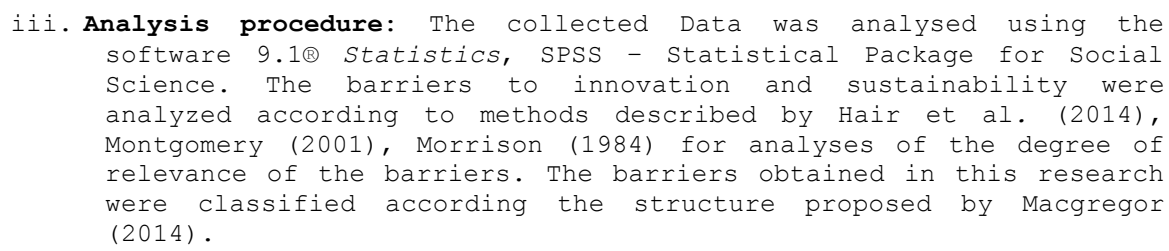

4. Resulting barriers to Innovation and Sustainable Development in Universities

Table 1 contains 25 categories (fundamental barriers) that were identified in Phase 1 of the research by the content analyses. The table also lists examples of reported studies (citations) that have investigated such barriers and these confirm that all of the barriers identified by the informants of Phase 1 have been also identified by previous research. 
Table 1: Barriers to innovation and SD at universities identified from Phase 1

\begin{tabular}{|c|c|c|}
\hline $\mathbf{N}^{0}$ & $\begin{array}{l}\text { Categories that emerged from the } \\
\text { interviews - Barriers }\end{array}$ & Authors of literature associated with the categories \\
\hline 1 & $\begin{array}{l}\text { Lack of planning and focus on the } \\
\text { topic. }\end{array}$ & $\begin{array}{l}\text { Brandli et al., (2015); Hansen and Grobe-Dunker (2013); } \\
\text { Reidand Schwab (2006); Dahle e Neumayer (2001) }\end{array}$ \\
\hline 2 & Lack of environmental committee. & $\begin{array}{l}\text { Nidumolu, Prahalad, and Rangaswami (2009); Tauchen and } \\
\text { Brandli (2006) }\end{array}$ \\
\hline 3 & $\begin{array}{l}\text { Lack of applicability and continuity of } \\
\text { innovation and sustainability actions. }\end{array}$ & Brandli et al., (2015); Van Ginkel (1996) \\
\hline 4 & Resistance to changes in behavior. & $\begin{array}{l}\text { Barbieri et al., (2010); Brandli et al., (2015); Dahle e } \\
\text { Neumayer (2001) }\end{array}$ \\
\hline 5 & $\begin{array}{l}\text { Lack of commitment towards } \\
\text { innovation and sustainability. }\end{array}$ & $\begin{array}{l}\text { Elliot e Wright (2013); Dahle and Neumayer (2001); } \\
\text { Brandli et al., (2015) }\end{array}$ \\
\hline 6 & Lack of Training and collaboration. & Brandli et al., (2015); Elliot and Wright (2013) \\
\hline 7 & $\begin{array}{l}\text { Strong culture and conservatism } \\
\text { between people involved parties. }\end{array}$ & $\begin{array}{l}\text { Brandli et al., (2015); Dahle and Neumayer (2001); Jackson } \\
\text { (2005); Reid and Schwab (2006) }\end{array}$ \\
\hline 8 & $\begin{array}{l}\text { Lack of research and development } \\
\text { (planning, projects, research). }\end{array}$ & $\begin{array}{l}\text { Brandli et al., (2015); Veiga (2014); Elliot and Wright } \\
\text { (2013); }\end{array}$ \\
\hline 9 & $\begin{array}{l}\text { Lack of awareness and concern (both } \\
\text { staff and faculty) }\end{array}$ & $\begin{array}{l}\text { Elliot e Wright (2013); Dahle and Neumayer (2001); } \\
\text { Brandliet al., (2015) }\end{array}$ \\
\hline 10 & $\begin{array}{l}\text { Lack of building with appropriate } \\
\text { sustainable performance. }\end{array}$ & Dahle and Neumayer (2001); Van Ginkel (1996) \\
\hline 11 & $\begin{array}{l}\text { Lack of support and involvement of the } \\
\text { University administration. }\end{array}$ & $\begin{array}{l}\text { Brandli et al., (2015); Dahle and Neumayer (2001); Hansen } \\
\text { e Grobe-Dunker (2013); Leal filho, Shiel e Paço (2015) }\end{array}$ \\
\hline 12 & Lack of appropriate technology. & Dahle and Neumayer (2001); \\
\hline 13 & $\begin{array}{l}\text { Lack of integration of teaching, } \\
\text { research and extension } \\
\text { campus and departments). }\end{array}$ & $\begin{array}{l}\text { Waas et al. (2012); Brandli et al. (2015); Meyerson e Massy } \\
\text { (1995) }\end{array}$ \\
\hline 14 & $\begin{array}{l}\text { Lack of dialogue (campus, departments } \\
\text { and commissions) }\end{array}$ & $\begin{array}{l}\text { Waas et al. (2012); Brandli et al. (2015); Meyerson e Massy } \\
\text { (1995); Van Ginkel (1996) }\end{array}$ \\
\hline 15 & $\begin{array}{l}\text { Institutional barriers } \text { (excessive } \\
\text { standards and requirements). }\end{array}$ & $\begin{array}{l}\text { Brandli et al., (2015); Dahle and Neumayer (2001); Leal } \\
\text { (2000); Leal Filho, Shiel and Paço (2015); Reid and } \\
\text { Schwab (2006); Wright (2002) }\end{array}$ \\
\hline 16 & $\begin{array}{l}\text { Lack of support for the introduction of } \\
\text { control system (resources and } \\
\text { professionals). }\end{array}$ & $\begin{array}{l}\text { Brandli et al., (2015); Cameron (1996); Crossan and } \\
\text { Apaydin (2010); European Commission (2016); Ferreira e } \\
\text { Dionísio (2016); Hart and Milstein (2003); Hockerts and } \\
\text { Morsing (2008); Nidumolu et al., (2009); Paech (2007); } \\
\text { Clugston (1999) }\end{array}$ \\
\hline 17 & Lack of defined policies and practices. & $\begin{array}{l}\text { Brandli et al., (2015); Leal Filho, Shiel and Paço (2015); } \\
\text { Novicki and Souza (2010); Clugston (1999) }\end{array}$ \\
\hline 18 & $\begin{array}{l}\text { Lack of support in the introduction of } \\
\text { control system (resources and }\end{array}$ & Crossan and Apaydin (2010); Glavik and Lukman (2007) \\
\hline
\end{tabular}




\begin{tabular}{|c|c|c|}
\hline & professionals). & \\
\hline 19 & $\begin{array}{l}\text { Many restrictions and bureaucracy } \\
\text { (excessive formalities and delay) }\end{array}$ & $\begin{array}{l}\text { Wright (2002); Meyerson e Massy (1995); Dahle e } \\
\text { Neumayer (2001) }\end{array}$ \\
\hline 20 & $\begin{array}{l}\text { Lack of Knowledge and education } \\
\text { about the topic. }\end{array}$ & $\begin{array}{l}\text { Brandli et al., (2015); Barbieri and Silva (2011); Cars and } \\
\text { West (2015); Dahle and Neumayer (2001); Elliot and } \\
\text { Wright (2013); Leal Filho (2000) }\end{array}$ \\
\hline 21 & $\begin{array}{l}\text { Lack of capacity for decision making } \\
\text { (on part of managers. }\end{array}$ & Dahle e Neumayer (2001); Brandli et al., (2015) \\
\hline 22 & $\begin{array}{l}\text { Lack of Entrepreneurship and public- } \\
\text { private partnerships (few relationships } \\
\text { between the public and private } \\
\text { institutions). }\end{array}$ & $\begin{array}{l}\text { Waas et al. (2012); Riera (1996); Creigghton (1999); Dahle } \\
\text { e Neumayer (2001) }\end{array}$ \\
\hline 23 & $\begin{array}{l}\text { Social barriers (conflicts between } \\
\text { approaches, consumption behavior and } \\
\text { unsustainable actions). }\end{array}$ & $\begin{array}{l}\text { Waas et al. (2012); Brandli et al. (2015); Dahle e } \\
\text { Neumayer (2001) }\end{array}$ \\
\hline 24 & $\begin{array}{l}\text { Government barriers (economic and } \\
\text { political model of actions not included; } \\
\text { Lack of legislation and guidelines for } \\
\text { sustainability and innovation. }\end{array}$ & $\begin{array}{l}\text { Brandli et al., (2015); Dahle and Neumayer (2001); Leal } \\
\text { (2000); Leal Filho, Shiel e Paço (2015); Reid and Schwab } \\
\text { (2006); Wright (2002) }\end{array}$ \\
\hline 24 & Legislation and guidelines. & Waas et al. (2012); Meyerson e Massy (1995) \\
\hline
\end{tabular}

The list of barriers obtained in this study is aligned with much research that has been discussed for some time, although some of them are only focused on the implementation of Sustainable Development at universities (Glavič and Lukman, 2007; Waas et al, 2012; Brandli et al, 2015, Leal Filho, Shiel e Paço, 2015) or on innovation at universities (Cameron, 1996; Clugston, 1999; Crossan and Apaydin, 2010; Dahle and Neumayer, 2001; Hart and Milstein, 2003; Paech, 2007; Hockerts and Morsing, 2008; Nidumolu et al., 2009; Barbieri and Silva, 2011; Hockerts and Morsing, 2008; Cars and West, 2015; European Commission, 2016; Ferreira and Dionísio, 2016 ), and do not have an integrated vision about innovation and SD. The evaluation of the importance of the barriers identified in Table 1 points out the fifteen most significant barriers according to the results of the Likert scale (for each scale there was a weight correspondent, for example, the scale 5 expressed a greater degree of relevance in comparison to weight 1). Table 2 shows the results of the statistical analysis and Figure 2 illustrates the score of importance of the barriers in terms of the degree with which they influenced the process of innovation and sustainable development at universities.

Table 2: Results of statistical analysis Phase 2

\begin{tabular}{c|c|c|c|c|c}
\hline $\mathbf{N}^{\mathbf{9}}$ & Variable - Barriers & Average* & $\begin{array}{l}\text { Standart } \\
\text { deviation }\end{array}$ & Variance & Sum \\
\hline
\end{tabular}




\begin{tabular}{|c|c|c|c|c|c|}
\hline 11 & Administration & 3.9 & 1.0 & 1.0 & 134 \\
\hline 12 & Technology & 2.7 & 1,0 & 1.0 & 95 \\
\hline 09 & Conscience and concern & 2.6 & 1.1 & 1.2 & 90 \\
\hline 02 & Environmental Committee & 2.6 & 1.2 & 1.5 & 89 \\
\hline 10 & Building & 2.6 & 1.2 & 1.4 & 89 \\
\hline 24 & Government Barriers & 2.5 & 1.1 & 1.2 & 85 \\
\hline 08 & Research and development & 2.4 & 1.1 & 1.4 & 84 \\
\hline 18 & Support for the introduction of control systems & 2.4 & 1.0 & 1.1 & 82 \\
\hline 23 & Social barriers & 2.3 & 1.1 & 1.2 & 81 \\
\hline 25 & Legislation and guidelines & 2.3 & 1.3 & 1.8 & 81 \\
\hline 20 & Knowledge and education & 2.3 & 1.1 & 1.3 & 79 \\
\hline 3 & Applicability and continuity & 2.2 & 1.1 & 1.3 & 78 \\
\hline 6 & Training and collaboration & 2.2 & 1.1 & 1.4 & 78 \\
\hline 15 & Institutional barriers & 2.2 & 1.1 & 1.3 & 78 \\
\hline 17 & Practice and policies & 2.2 & 1.0 & 1.0 & 78 \\
\hline 16 & Incentives for innovation & 2.2 & 1.3 & 1.7 & 76 \\
\hline 19 & Restrictions and bureaucracy & 2.2 & 1.1 & 1.2 & 75 \\
\hline 01 & Planning and focused & 2.1 & 1.0 & 1.0 & 74 \\
\hline 07 & Culture and conservatism & 2.1 & 0.8 & 0.6 & 74 \\
\hline 22 & Entrepreneurship and public-private partnerships & 2.0 & 1.0 & 1.1 & 71 \\
\hline 14 & Dialogue & 2.0 & 1.0 & 1.0 & 70 \\
\hline 05 & $\begin{array}{l}\text { Commitment towards innovation and } \\
\text { sustainability }\end{array}$ & 1.9 & 1.1 & 1.2 & 67 \\
\hline 21 & Capacity and decision & 1.9 & 0.7 & 0.5 & 67 \\
\hline 13 & Integration of teaching, research and extension & 1.9 & 0.9 & 0.9 & 65 \\
\hline 04 & Resistance to changes in behaviour & 1.8 & 1.0 & 1.1 & 62 \\
\hline
\end{tabular}

*Average has been calculated according the value attributed to score of Likert Scale: $5=$ totally agree; 4 = Agree; $3=$ Neutral; 2 = Disagree; 1 = Totally disagree.

\section{Analyses of the barriers to innovation and sustainability at universities}

Although the values attributed by the interviewees was low (on average, most of them considered the barriers neutral), the results can indicate a distribution in the weight of barriers, which means that a group of barriers may affect innovation and SD at universities. 


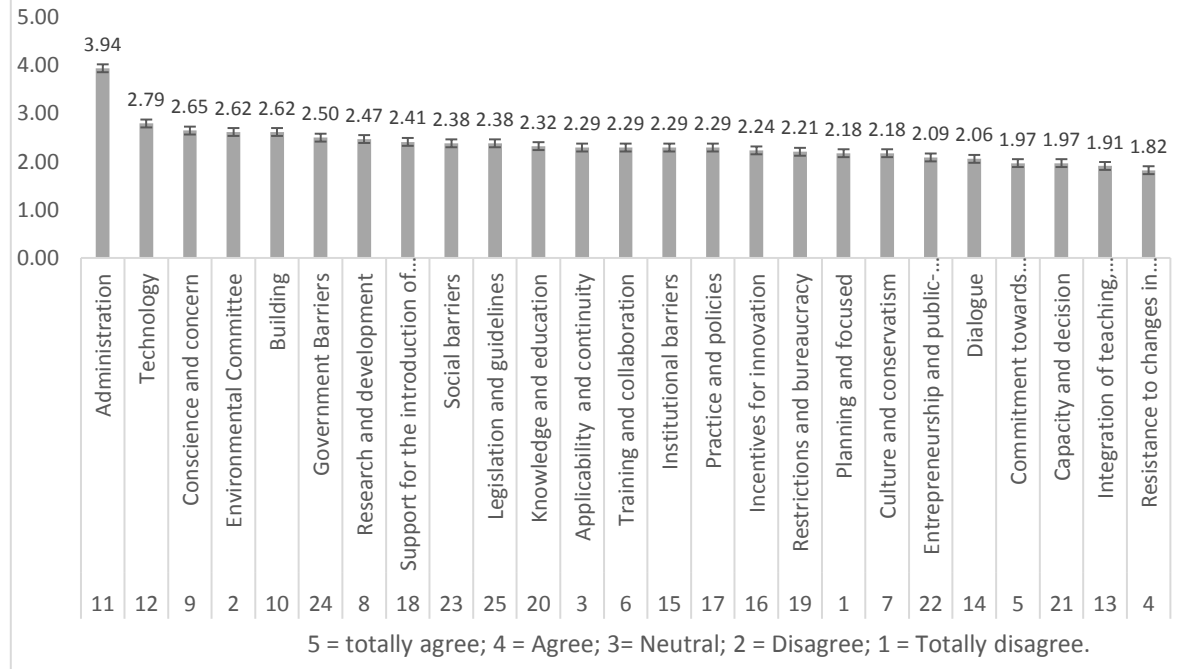

Figure 2: Relevance of the barriers to innovation and SD at universities

The administration of the universities is the main barrier that influences the process of innovation and sustainable development at universities. This is followed by a lack of technology, lack of conscience and concern, lack or inefficiency of environmental committee and a lack of sustainable buildings. Also cited are governmental barriers, research and development, support for the introduction of control systems, social barriers, legislation and guidelines, knowledge and education, applicability and continuity, training and collaboration, institutional barriers, and practice and policy barriers.

A broad understanding of the nature and magnitude of the barriers to innovation and sustainability at universities in an international context is important to managers, the academic community and especially to campus managers, who seek to develop strategies and actions in this area. The results gathered from the study performed in the context of this paper, show that the largest number of barriers are within the area of management (i.e. university administration, environmental committees, in research and development, in the introduction and/or support of control systems, in terms of legislation and formal guidelines, and with respect to knowledge and education). Other barriers are in the areas of policies, infrastructure, resources, capacity and institutional culture. A university that is seeking to go towards a more sustainable path is bound to face a series of internal and external barriers (Brandli et al., 2015). It is therefore necessary to deal with these barriers in a systematic manner, so that they may not negatively influence further developments and not lead to a loss of interest from the side of the community involved.

One particular barrier, namely the lack of support from the university administration (score: 3.94) seems to be the biggest obstacle according to the respondents. One of the major problems among university administrators is that there may not be an understanding that 
sustainability and innovation in universities are among the main strategies to help them to address social and economic inequalities. Operationally, such integration could be achieved by means of the creation of a sustainable campus and by fostering the training of students through teaching practices (Stir, 2006; Lozano et al., 2013). But one may ask whether or not current university administrations are aware (or give importance) to work in this area or support to actions in these fields. It is observed that a lack of support from university administrations has a direct influence on the other barriers, which are essential for the development and integration of the university campus.

The integration of sustainability principles on a university campus can be achieved by perceiving such campuses as places where new ideas can be tested, new opportunities can be explored, and by regarding them as habitats where the development and implementation of new technologies, new innovations and new management strategies with a focus on sustainability in scale can take place (Evans et al., 2015; Alshuwaikhat and Adam, 2008). Universities should be seeking to improve the possibilities of expanding innovations out of their "walls", through a process of continuous learning, not only within the universities themselves, but in close collaboration with municipalities and the private sector (Trencher, 2014). Dlouhá, Glavič and Barton (2016), when analyzing the critical factors for sustainability transition in HEI, argue that to reach ESD innovations, research activities and innovation in the context of university curricula, extensive changes in teaching/learning processes are essential.

According to the participants of this study, a lack of appropriate technology (score: 2.79 ) and a lack of suitable buildings (score: 2.71) are some of the other major barriers that prevent the development of many actions, projects and the integration of sustainability principles on campuses. Therefore, a better performance in these areas is important in order to achieve structural and operational improvements, to better engage the various actors, and to generate ideas and the involvement of the academic community. It is especially important to raise the awareness of and concern for these issues from both staff and students (score: 2.64). These measures may help to overcome the challenges, and may also help to create a sense of identity between universities and the community (Clarke and Kouri, 2009).

The fourth major barrier when it comes to the development of innovation and sustainability, is the lack of formal settings, such as an "environmental committee" (score: 2.61). Such committees have a key role to play as they assist in the development of more sustainable universities through actions towards the reduction of their environmental impacts, as well as in the promotion of education, research, and the development of new initiatives for sustainable development.

An analysis indicates that many universities have not yet advanced in a number of areas that are required for the full implementation of sustainable development principles. In most cases, adjustments in campus operations are required, to be supported by best practices to improve both performance and the fostering of relationships with the key actors both within and without universities.

In terms of the domains of campus innovation, Velazquez et al (2005) propose four areas (research, campus, education, outreach). Jones, Selby and Sterling (2010) also demonstrate a structure, but with a key difference: they include culture and research as an integral part of curriculum. Analyzing the barriers obtained for an area, it can be noted that no 
single one of these structures is suitable. An adaptation that includes the "Leadership and Governance" and "Partnership and Engagement" in the structure proposed by Macgregor (2014) seems to be appropriate for the framing of the barriers.

Figure 3 shows the structure based on Macgregor (2014) and the classifications of the barriers. The barriers presented illustrate areas where development is lagging behind in this process of innovation and SD at universities, especially with respect to leadership and governance and learning, teaching and research.

Figure 3 - Barriers according the domains

\section{Conclusions}

There has been a noticeable increase in the number of discussions regarding teaching and research when it comes to sustainable development over recent decades. Despite this, there are not many studies which investigate the relationship between innovation and sustainability, even when there is evidence to suggest that by converging these two processes long term impacts and benefits are achieved.

This research has identified a set of gaps in knowledge which need to be fulfilled. First of all, when a university seeks to implement sustainability initiatives as part of its daily activities, a set of barriers are encountered. As this paper has pointed out, even though many 
of these barriers are well known, they still exist. Additionally, the main barriers found for the deployment of innovation and sustainability tend to be associated with management (i.e. university administration, environmental committees, the introduction and/or support of management systems; management in terms of policy and formal guidelines). Other barriers faced are those associated with technology, resource availability and institutional culture. However, even if these other barriers are tackled, without addressing issues associated with management little progress may be expected.

A further item worthy of attention here is the fact that a lack of support from the university administration is one of the most important obstacles faced when trying to implement sustainability within the institution. Unfortunately, this study showed that many university leaders do not yet see the importance of innovation and sustainability when it comes to addressing issues such as social and economic inequalities throughout the university. It is important that decision makers and the general community see campuses as places for opportunities and areas that can be the birthplace for new management strategies and the deployment of technologies.

Moreover, this study has shown that many universities which participated in the research need several adjustments in their campus operations. Most have not yet elaborated a document that states their goals or overall mission when it comes to sustainability. Further, a number of universities have not established and/or are not pursuing sustainability goals, and have not yet fostered effective relationships with stakeholders from within and outside of the university.

The implications of the research here are clear: there is a need for a change of thinking with respect to the fact that sustainability should not only be part of campus operations, but that it should also be a part of teaching and research. Sustainability should be embedded in the relationships with external partners (e.g. industry) in order to unlock opportunities for investments in education, infrastructure and technological research.

\section{References}

\section{AFRHINET. http://afrhinet.eu/ (Accessed in 13.03.17)}

Alnsour, J.A., Meaton, J. 2015. The use of university research in planning decision making in Jordanian municipalities. Habitat International, Vol. 49, pp. 206-211. https://doi.org/10.1016/j.habitatint.2015.05.010

Alshuwaikhat, H.M., Abubakar, I. 2008. An integrated approach to achieving campus sustainability: assessment of the current campus environmental management practices. J. Clean. Prod. ournal of Cleaner Production, Vol. 16, No. (16), pp., 1777-1785. https://doi.org/10.1016/j.jclepro.2007.12.002

Babbie, E.R. 2009. The practice of social research (12th Ed.), Wadsworth Publishing, Bedmont, California, USA.

Barbieri, J. C.; Silva, D. 2011. Desenvolvimento sustentável e educação ambiental: uma trajetória comum com muitos desafios. Revista de Administração da Mackenzie, 12, 3, 51-82. 
Barbieri, J.C., Vasconcelos, I.F.G de, Andreassi, T., and Vasconcelos, F.C.G de. 2010. Innovation and sustainability: New Models and Propositions. RAE, Vol. 50 (No. 2), pp. 146154

Bardin, L. 2011. Análise de conteúdo. LDA, Lisboa, Portugal.

Barth M et al 2007. Developing key competencies for sustainable development in higher education. International Journal of Sustainability in Higher Education, v. 8, n. 4, p. 416-430

Bero, B.N., Doerry, E., Middleton, R., \& Meinhardt, C. 2012. Challenges in the development of environmental management systems on the modern university campus. International Inter. J.ournal of S Sustain.ustainability in Hi High.er Educ.ation, Vol. 13 No. (2), pp. 133-149. https://doi.org/10.1108/14676371211211827

Bessant, J., Tidd, J. 2009. Inovação e empreendedorismo. Porto Alegre: Bookman.

Brandli, L.L., Leal Filho, W., Frandoloso, M.A.L., Korf, E.P., \& Daris, D. 2015. The Environmental Sustainability of Brazilian Universities: Barriers and Pre-conditions. In Integrating Sustainability Thinking in Science and Engineering Curricula, pp. 63-74. Springer International Publishing.

Cameron, G. 1996. Innovation and economic growth. CEPDP, 277. Centre for Economic Performance, London School of Economics and Political Science, London, UK. ISBN 0753003007

Capdevila, I., Bruno, J., Jofre, L. 2002. Curriculum greening and environmental research coordination at the Technical University of Catalonia, Barcelona. Journal of Cleaner Production, Vol. 10 No. 1, pp. 25-31.

Clarke, A., Kouri, R. 2009. "Choosing an appropriate university or college environmental management system", Journal of Cleaner Production, Vol. 17, pp. 971-84.

Cortese, A.D. 2003. 'The Critical Role of Higher Education in Creating a Sustainable Future', Planning for Higher Education, March-May, pp. 15-22.

Courtice, P. Van der Kamp M. 2013. Developing leaders for the future: Integrating sustainability into mainstream leadership programmes. Working paper of the Cambridge Programme for Sustainability Leadership, commissioned by the Academy of Business in Society.

Creighton, S. H. 1999. Greening the Ivory Tower. Improving the Environmental Track Record of Universities, Colleges, and Other Institutions. MIT Press, Cambridge (Mass).

Crossan, M.M., Apaydin, M. 2010. A Multi-Dimensional Framework of Organizational Innovation: A Systematic Review of the Literature. Journal of Management Studies, Vol. 47 No. 6, September, doi: 10.1111/j.1467-6486.2009.00880.x

Dahle, M., Neumayer, E. 2001. Overcoming barriers to campus greening: a survey among higher educational institutions in London, UK. International Journal of Sustainability in Higher Education, Vol. 2 No. 2, pp. 139-60.

Del Rio, P., Carrillo-Hermossilla, J., Könnöla, T. 2010. Policy strategies to promote ecoinnovation; an integrated frame work. Journal of Industrial Ecology, 14 (4), pp 541-557. 
Djordjevic, A. Cotton, D.R.E. 2011. Communicating the sustainability message in higher education institutions. International Journal of Sustainability in Higher Education, Vol. 12 No. 4, pp. 381-394.

Dlouhá, J., et al. Higher education in Central European countries e Critical factors for sustainability transition, Journal of Cleaner Production (2016), http://dx.doi.org/10.1016/j.jclepro.2016.08.022

Ecocampus.2017 http://moodle.loreus.com/( Accessed in 13.03.17)

Elliot, H., Wright, T. 2013. Barriers to sustainable universities and ways forward: A Canadian students' perspective. The 3rd World Sustainability Forum. 1-30 November.

European Commission 2016. European Innovation Union Scoreboard 2016. http://www.knowledgetransferireland.com/About_KTI/Reports-Publications/EuropeanInnovation-Scoreboard-2016.pdf (Accessed in 11/03/2017)

Evans, J., Jones, R., Karvonen, A., Millard, L., Wendler, J. 2015. Living labs and coproduction: university campuses as platforms for sustainability science. Current Opinion in Environmental Sustainability, Vol. 16,pp. 1-6.https://doi.org/10.1016/j.cosust.2015.06.005

Ferreira, P.J.S., Dionísio, A.T.M. 2016. What are the conditions for good innovation results? A fuzzy-set approach for European Union. Journal of Business Research, Vol. 69, pp. 53965400 India, China, South Africa, Turkey and Singapore. J. Cleaner Prod. 130, 235-247

Green Sustainability Metrics 2016. http://wonkhe.com/blogs/latest-green-metric-worldranking/ (Accessed in 03.13.2017)

Gombert-Courvoisier S et al 2014. Higher Education for Sustainable Consumption: case report on the Human Ecology Master' s course (University of Bordeaux, France), Journal of Cleaner Production, n. 62, p. 82-88. http://dx.doi.org/10.1016/j.jclepro.2013.05.032

Gudz, N.A. 2004. Implementing the sustainable development policy at the University of British Columbia: An analysis of the implications for organizational learning. International Journal of Sustainability in Higher Education, Vol. 5 No. 2, pp. 156-168.

Hair JR., J.F., Babin, B., Money, A.H. Samouel, P. 2010. Fundamentos de métodos de pesquisa em administração. Tradução Lene Belon Ribeiro. Porto Alegre: Bookman. 471p.

Hansen, E.G. Grobe-Dunker, F. 2013. Sustainability-Oriented Innovation. Encyclopedia of Corporate Social Responsibility, Heidelberg, Vol. 1, pp. 2407-2417, 2013.< http://ssrn.com/abstract=2191679>. (Accessed in 20./06./16)

Hansen, J. A., Lehmann, M. 2006. Agents of change: universities as development hubs. Journal of Cleaner Production, Vol. 14 No. 9-11, pp.820-829. https://doi.org/10.1016/j.jclepro.2005.11.048

Hart. M., Milstein, M. 2003. "Creating Sustainable Value," Academy of Management Executive, Vol. 17 No. 2 (2003). Also see Stuart Hart, Capitalism at the Crossroads Philadelphia: Wharton School Publishing.

Hellström, T. 2007. Dimensions of environmentally sustainable innovation: the structure of eco-innovation concepts. Sustainable Development, Vol. 15, pp. 148-159. 
Hockerts, K. , and Morsing. M. Morsing, M. 2008. A literature review on corporate social responsibility in the innovation process. Copenhagen Business School (CBS), Center for Corporate Social Responsibility, pp. 1-28.

Jones P, Selby D, Sterling S., 2010. Sustainability education: perspectives and practice across higher education. Earth scans Publishing, London

Larrán Jorge, M., Herrera Madueño, J., Calzado Cejas, M. Y. \& Andrades Peña, F. J. 2014. An approach to the implementation of sustainability practices in Spanish universities. Journal of Cleaner Production. https://doi.org/10.1016/j.jclepro.2014.07.035

Lauder, A., Sari, R,F., Suwartha, N., Tjahjono, G. 2015. Critical review of a global campus sustainability ranking: GreenMetric. Journal of Cleaner Production, Vol.108, Part A, pp 852863.

Leal Filho, W. (Ed.) 2006. Innovation, Education and Communication for Sustainable Development. Peter Lang Scientific Publishers, Frankfurt.

Leal Filho, W., Salomone, M. (Eds) 2006. Innovative Approaches to Education for Sustainable Development. Peter Lang Scientific Publishers, Frankfurt.

Leal Filho, W., Santana, N., Rebelatto, D. A. N., Perico, A. E., Moralles, H.C. 2015. Technological innovation for sustainable development: an analysis of different types of impacts for countries in the BRICS and G7 groups. In International Journal of Sustainable Development \& World Ecology, 22:5, 425-436. DOI: 10.1080/13504509.2015.1069766

Leal Filho., W, Shiel C., Paço, A, do. 2015. Integrative approaches to environmental sustainability at universities: an overview of challenges and priorities. Journal of Integrative Environmental Sciences, Vol. 12, pp. 1-14.

Leal Filho, W. 2000. Dealing with misconceptions on the concept of sustainability. International Journal of Sustainability in Higher Education, Vol. 1 No. 1, pp. 9-19.

Leal Filho, W. Shiel, C. ; do Paço, A. do ; Brandli, L. (2015) Putting sustainable development in practice: Campus Greening as a Tool for Institutional Sustainability Efforts. In: Paulo Davim. (Org.). Sustainability in Higher Education. 1ed.Londres: Elsevier, Vol 1, pp. 1-19. http://dx.doi.org/10.1016/B978-0-08-100367-1.00001-9

Levy, B.L.M., Marans, R.W., 2012. Towards a campus culture of environmental sustainability. International Journal of Sustainability in Higher Education, Vol. 13No. 4, pp. 365-377. https://doi.org/10.1108/14676371211262317

Likert, R. 1932. A Technique for the Measurement of Attitudes. Archives of Psychology, Vol. 140, pp. 5-53.

Lozano, R., Lozano, F.J., Mulder, K., Huisingh, D., Waas, T. 2013. Advancing higher education for sustainable development: international insights and critical reflections. Journal of Cleaner Production, Vol. 48, pp. 3-9.

Lozano, R., Lukman, R., Lozano, F.J., Huisingh, D., Lambrechts, W. 20112013. Declarations for sustainability in higher education: becoming better leaders, through addressing the university system, Journal of Cleaner Production, Vol 48, pp. 1-1010-19 
Lukman, R., Krajnc, D., Glavic, P. 2010. University ranking using research, educational and environmental indicators. Journal of Cleaner Production, Vol.18, pp. 619-628.

Macgregor, C.J. 2015. 'James Cook University's holistic response to the sustainable development challenge' in Leal, W. (ed.) Transformative approaches to sustainable development at universities: working across disciplines. Peter Lang Scientific Publishers. p 25-40.

MALHOTRA, N. 2006. Pesquisa de marketing: uma orientação aplicada. 4.ed. Bookman, Porto Alegre

Meyerson, J.W., Massy, W. F. (eds). 1995. Revitalising Higher Education. Peterson's, Princeton, New Jersey.

Montgomery. D. C. 2001. Design and analysis of experiments. 5. Ed. John Wiley \& Sons.

Moraes, R. 1999. Análise de conteúdo. Revista Educação, Portugal, Vol. 9 No. 37, pp. 7-32.

Morland-Painter, M., Sabet, E., Molthan-Hill, P., Goworek, H., De Leeuw, S. 2015. Beyond the curriculum: integrating sustainability into business schools, Journal of Business Ethics. ISSN 1573-0697

Morrison. 1984. Multivariate statistical methods. 2. Ed. International Student Edition.

Mozzato, A.R ., Grzybovski, D., 2011. Análise de Conteúdo como técnica de análise de dados qualitativos no campo da administração: potencial e desafios. Revista de Administração Contemporânea RAC.

Müller-Christ, G., Sterling, S., van Dam-Mieras, R., Adomßent, M., Fischer, D., Rieckmann, M. 2014. The role of campus, curriculum, and community in higher education for sustainable development - a conference report. Journal of Cleaner Production, Vol. 62, pp. 134-137. https://doi.org/10.1016/j.jclepro.2013.02.029

Nidumolu, R., Prahalad, C. K., Rangaswami, M.R., 2009. Why Sustainability Is Now the Key Driver of Innovation. Harvard Business Review, pp. 57-64.

Novicki, V., Souza, D.B.D. 2010. Políticas públicas de educação ambiental e a atuação dos Conselhos de Meio Ambiente no Brasil: perspectivas e desafios. Ensaio: aval. pol. públ. Educ., Rio de Janeiro, Vol. 18 No. 69, pp. 711-736, out./dez.

Paech, N. 2007. Angst essen (ökologische) Seele auf, in: Lang, E./Busch-Lüty, C./Kopfmüller, J. (Hrsg.): Ansätze für eine Ökonomie der Nachhaltigkeit, München, pp. 227-230

People, Planet League. 2017. https://peopleandplanet.org/university-league (Accessed in 13.03.17)

Pereira, G.D.S.M., Jabbour, C., Oliveira, S.V.W.B. De \& Teixeira, A.A. 2014. Greening the campus of a Brazilian university: cultural challenges. International Journal of Sustainability in Higher Education, Vol. 15 No. 1, pp. 34-47.https://doi.org/10.1108/IJSHE-10-2011-0067

Perkmann, M., Tartari, V., McKelvey, M., Autio, E., Broström, A., D’Este, P., Fini, R., Geuna, A., Grimaldi, R., Hughes, A., Krabel, S., Kitson, M., Llerena, P., Lissoni, F., Salter, A., Sobrero, M. 2013. Academic engagement and commercialisation: A review of the literature on university-industry relations. Research Policy, Vol.42, pp. 423-442. 
Posch, A., Steiner, G., 2006. Integrating research and teaching on innovation for sustainable development. International Journal of Sustainability in Higher Education, Vol. 7 No. 3, pp.276-292.

Reid, M., Schwab, W. 2006. Barriers to Sustainable Development. Journal of Asian and African Studies, Vol 41 No. 5/6, pp. 439-457 - DOI: 10.1177/0021909606067408, London.

Richardson, G.R., Lynes, J.K. 2007. Institutional motivations and barriers to the construction of green buildings on campus: A case study of the University of Waterloo, Ontario. International Journal of Sustainability in Higher Education, Vol. 8 No. 3, pp. 339-354.

Riera, P., 1996. Environmental Policy at the Universit at Autonomia de Barcelona. In Leal Filho, W., MacDermot, F., and Padgam, J. (eds.) Implementing Sustainable Development at University Level - A Manual of Good Practice. Cre-Copernicus, Bradford.

Ryan, A., Tilbury, D. 2013. Uncharted waters: Voyages for education for sustainable development in the higher education curriculum. Curriculum Journal, Vol. 24 No. 2, pp. 272 294.

Ryan, A., Tibury, D, Corcoran, B, P., Abe, O, Nomura, K. 2010. Sustainability in higher education in the Asia- Pacific: developments, challenges, and prospects. International Journal of Sustainability in Higher Education, 11, 2, 106 -119.

Saleh, A. A., Kamarulzaman, N., Hashim, H., Hashim, S. Z. 2011. An Approach to Facilities Management (FM) Practices in Higher Learning Institutions to Attain a Sustainable Campus (Case Study: University Technology Mara-UiTM). Procedia Engineering, Vol. 20, pp. 269278.

Shiel, C., Leal Filho, W., do Paço, A., Brandli, L. 2016. Evaluating the engagement of universities in capacity building for sustainable development in local communities. Evaluation and program planning, Vol. 54, pp. 123-134.

Simon, D. Lundebye, A. 2013. Stepping outside a comfort zone: transdisciplinary innovation in sustainability education. In Atfield and Kemp (eds.) Enhancing education for sustainable development in business and management, Hospitality, Leisure, Marketing, Tourism. HEA: York

Stir, J. 2006. Restructuring teacher education for sustainability: student involvement through a "strengths model." Journal of Cleaner Production, Vol. 14 No. 9-11, pp. 830836.https://doi.org/10.1016/j.jclepro.2005.11.051.

Tauchen, J., Brandli, L. L. 2006. A Gestão Ambiental em Instituições de Ensino Superior: modelo para implantação em Campus universitário. Revista Gestão e Produção, Vol. 13, No. 3, pp. 503-515, setembro - dezembro.

Thomashow, M., 2014, The Nine Elements of a Sustainable Campus. London: The MIT Press.236p

Trencher, G., Bai, X., Evans, J., McCormick, K. \& Yarime, M. 2014. University partnerships for co-designing and co-producing urban sustainability. Global Environmental Change, Vol. 28, pp. 153-165. 
ULSF, 2007. Talloires Declaration Institutional Signatory List Retrieved $24^{\text {th }}$ Septebmer, 2007, http://www.ulsf.org/programs_talloires_signatories. html . (accessed 10.03.17).

Van Ginkel, H.J.A. 1996. "Implementing sustainable development: a case study", in Leal Filho, W., MacDermot, F. and Padgam, J. (Eds), Implementing Sustainable Development at University Level - A Manual of Good Practice, CRE- COPERNICUS, Bradford.

Velazquez, L., Munguia, N.,\& Sanchez, M. 2005. Deterring sustainability in higher education institutions. International Journal of Sustainability in Higher Education, Vol. 6 No. 4, pp. 383-391.https://doi.org/10.1108/14676370510623865

Vergara, S. C. 2005. Métodos de pesquisa em administração. São Paulo: Atlas.

Vollenbroek, F. 2002. Sustainable Development and the challenge of innovation. Journal of Cleaner Production, Vol. 10, pp. 215-223.

Waas, T., Hugé, J., Ceulemans, K., Lambrechts, W., Vandenabeele, J., Lozano, R., Wright, T. 2012. Sustainable Higher Education - Understanding and Moving Forward. Flemish Government - Environment, Nature and Energy, Department, Brussels.

Winter, J. and Cotton, D. 2012. Making the hidden curriculum visible: sustainability literacy in higher education. Environmental Education Research, Vol. 18 No. 6, pp. 783-796.

Wright, T. 2002. Definitions and frameworks for environmental sustainability in higher education, International Journal of Sustainability in Higher Education, 3, 3, 203-220.

Wright, T. 2010. University presidents' conceptualizations of sustainability in higher education. International Journal of Sustainability in Higher Education, Vol. 11 No. 1, pp. 6173. doi:10.1108/14676371011010057

Yarime, M., Tanaka, Y. 2012. The Issues and Methodologies in Sustainability Assessment Tools for Higher Education Institutions: A Review of Recent Trends and Future Challenges. Journal of Education for Sustainable Development, Vol. 6 No. 63 